\title{
Front Matter: Volume 9090
}

, "Front Matter: Volume 9090," Proc. SPIE 9090, Automatic Target Recognition XXIV, 909001 (24 June 2014); doi: 10.1117/12.2074013

SPIE. Event: SPIE Defense + Security, 2014, Baltimore, MD, United States 


\section{PROCEEDINGS OF SPIE}

\section{Automatic Target Recognition XXIV}

Firooz A. Sadjadi

Abhijit Mahalanobis

Editors

5-6 May 2014

Baltimore, Maryland, United States

Sponsored and Published by

SPIE 
The papers included in this volume were part of the technical conference cited on the cover and title page. Papers were selected and subject to review by the editors and conference program committee. Some conference presentations may not be available for publication. The papers published in these proceedings reflect the work and thoughts of the authors and are published herein as submitted. The publisher is not responsible for the validity of the information or for any outcomes resulting from reliance thereon.

Please use the following format to cite material from this book:

Author(s), "Title of Paper," in Automatic Target Recognition XXIV, edited by Firooz A. Sadjadi, Abhijit Mahalanobis, Proceedings of SPIE Vol. 9090 (SPIE, Bellingham, WA, 2014) Article CID Number.

ISSN: 0277-786X

ISBN: 9781628410273

Published by

SPIE

P.O. Box 10, Bellingham, Washington 98227-0010 USA

Telephone +1 3606763290 (Pacific Time) · Fax +1 3606471445

SPIE.org

Copyright (c) 2014, Society of Photo-Optical Instrumentation Engineers.

Copying of material in this book for internal or personal use, or for the internal or personal use of specific clients, beyond the fair use provisions granted by the U.S. Copyright Law is authorized by SPIE subject to payment of copying fees. The Transactional Reporting Service base fee for this volume is $\$ 18.00$ per article (or portion thereof), which should be paid directly to the Copyright Clearance Center (CCC), 222 Rosewood Drive, Danvers, MA 01923. Payment may also be made electronically through CCC Online at copyright.com. Other copying for republication, resale, advertising or promotion, or any form of systematic or multiple reproduction of any material in this book is prohibited except with permission in writing from the publisher. The CCC fee code is 0277-786X/14/\$18.00.

Printed in the United States of America.

Publication of record for individual papers is online in the SPIE Digital Library.

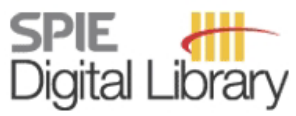

SPIEDigitalLibrary.org

Paper Numbering: Proceedings of SPIE follow an e-First publication model, with papers published first online and then in print and on CD-ROM. Papers are published as they are submitted and meet publication criteria. A unique, consistent, permanent citation identifier (CID) number is assigned to each article at the time of the first publication. Utilization of CIDs allows articles to be fully citable as soon as they are published online, and connects the same identifier to all online, print, and electronic versions of the publication. SPIE uses a six-digit CID article numbering system in which:

- The first four digits correspond to the SPIE volume number.

- The last two digits indicate publication order within the volume using a Base 36 numbering

system employing both numerals and letters. These two-number sets start with 00, 01, 02, 03, 04, $05,06,07,08,09,0 A, 0 B \ldots$. 0Z, followed by 10-1Z, 20-2Z, etc.

The CID Number appears on each page of the manuscript. The complete citation is used on the first page, and an abbreviated version on subsequent pages. Numbers in the index correspond to the last two digits of the six-digit CID Number. 


\section{Contents}

vii Conference Committee

\section{ADVANCED CONCEPT I}

909002 Unification of automatic target tracking and automatic target recognition [9090-1]

B. J. Schachter, Northrop Grumman Corp. (United States)

909003 Optimized sparse presentation-based classification method with weighted block and maximum likelihood model [9090-2]

J. He, T. Zuo, B. Sun, X. Wu, Beijing Normal Univ. (China); C. Chen, Naval Academy of Armament (China)

$909004 \quad$ Maritime vessel recognition in degraded satellite imagery [9090-3]

K. Rainey, S. Parameswaran, J. Harguess, Space and Naval Warfare Systems Ctr. Pacific (United States)

909005 Application of an image feature network-based object recognition algorithm to aircraft detection and classification [9090-4]

J. Straub, The Univ. of North Dakota (United States)

909006 Fusion-based approach for long-range night-time facial recognition [9090-5]

R. B. Martin, M. Sluch, K. M. Kafka, A. Dolby, R. Ice, B. E. Lemoff, West Virginia High

Technology Consortium Foundation (United States)

\section{ADVANCED CONCEPT II}

$909007 \quad$ Nonstationary noise propagation with sources [9090-7]

J. S. Ben-Benjamin, L. Cohen, The City Univ. of New York (United States)

909008 Passive detection, characterization, and localization of multiple LFMCW LPI signals (2014 ATR Best Paper Award) [9090-8]

B. Hamschin, J. Clancy, M. Grabbe, M. Fortier, The Johns Hopkins Univ. Applied Physics Lab.

(United States); J. Novak, ASD Space and Sensor Systems (United States)

\section{ACTIVE SENSOR PROCESSING}

9090 0A Ladar ATR via probabilistic open set techniques (2014 ATR Best Student Paper Award) [9090-11]

M. Scherreik, B. Rigling, Wright State Univ. (United States)

9090 OB Radar target identification using various nearest neighbor techniques [9090-12]

I. Jouny, Lafayette College (United States) 
9090 0C Automatic detection of pulsed radio frequency (RF) targets using sparse representations in undercomplete learned dictionaries (2014 ATR Best Paper Award) [9090-13]

D. I. Moody, D. A. Smith, S. P. Brumby, Los Alamos National Lab. (United States)

9090 OD Autonomous underwater pipeline monitoring navigation system [9090-14]

B. Mitchell, N. Mahmoudian, G. Meadows, Michigan Technological Univ. (United States)

ADVANCED SENSOR PROCESSING II

9090 OE Time-frequency filtering for classifying targets in nonstationary clutter (Invited Paper)

[9090-15]

V. T. Gomatam, P. Loughlin, Univ. of Pittsburgh (United States)

9090 OF Instantaneous frequency and the Wigner-Gabor signal [9090-16]

P. J. Loughlin, Univ. of Pittsburgh (United States)

$9090 \mathrm{OH}$ Cross-spectral TDOA and FDOA estimation (Invited Paper) [9090-9]

D. J. Nelson, U.S. Dept. of Defense (United States)

9090 ol Matrix superposition structure with a tree-based principle (Invited Paper) [9090-21]

A. Sokolnikov, Visual Solutions and Applications (United States)

\section{ADVANCED ALGORITHMS}

9090 OK Line fitting based feature extraction for object recognition [9090-31]

B. C. Li, Lockheed Martin Systems Integration-Owego (United States)

9090 OL Sparse representation for vehicle recognition [9090-19]

N. D. Monnig, Univ. of Colorado at Boulder (United States); W. Sakla, Air Force Research

Lab. (United States)

9090 0M Adaptive compressive sensing for target detection [9090-20]

A. Mahalanobis, R. Muise, Lockheed Martin Missiles and Fire Control (United States); S. Roy,

Univ. of Washington (United States)

9090 ON Automatic target recognition using group-structured sparse representation [9090-22] B. Sun, X. Wu, J. He, X. Zhu, Beijing Normal Univ. (China); C. Chen, Naval Academy of Armament (China)

\section{FACIAL AND ACTIVITY RECOGNITION}

909000 Automatic recognition of emotions from facial expressions (2014 ATR Best Student Paper Award) [9090-23]

H. Xue, I. Gertner, The City College of New York (United States)

9090 OP Robust person and object tracking in LWIR and VIS based on a new template matching method [9090-24]

T. Müller, Fraunhofer Institute of Optronics, System Technologies and Image Exploitation

(Germany) 
$90900 Q \quad$ Military personnel recognition system using texture, colour, and SURF features [9090-26]

M. E. Irhebhude, E. A. Edirisinghe, Loughborough Univ. (United Kingdom)

Author Index

Proc. of SPIE Vol. $9090909001-5$

Downloaded From: https://www.spiedigitallibrary.org/conference-proceedings-of-spie on 25 Apr 2023 Terms of Use: https://www.spiedigitallibrary.org/terms-of-use 
Proc. of SPIE Vol. $9090909001-6$

Downloaded From: https://www.spiedigitallibrary.org/conference-proceedings-of-spie on 25 Apr 2023 Terms of Use: https://www.spiedigitallibrary.org/terms-of-use 


\section{Conference Committee}

Symposium Chair

David A. Whelan, Boeing Defense, Space, and Security

(United States)

Symposium Co-chair

Nils R. Sandell Jr., Strategic Technology Office, DARPA (United States)

\section{Conference Chairs}

Firooz A. Sadjadi, Lockheed Martin Advanced Technology Laboratories (United States)

Abhijit Mahalanobis, Lockheed Martin Missiles and Fire Control (United States)

Conference Program Committee

Mohammad S. Alam, University of South Alabama (United States) Farid Amoozegar, Jet Propulsion Laboratory (United States) Mahmood R. Azimi-Sadjadi, Colorado State University (United States) David Casasent, Carnegie Mellon University (United States) Leon Cohen, Hunter College, The City University of New York (United States)

Frederick D. Garber, Wright State University (United States) Guillermo C. Gaunaurd, Consultant (United States) Izidor Gertner, The City College of New York (United States) Patti S. Gillespie, U.S. Army Research Laboratory (United States) Riad I. Hammoud, BAE Systems (United States) Bahram Javidi, University of Connecticut (United States) Ismail I. Jouny, Lafayette College (United States)

Behzad Kamgar-Parsi, U.S. Naval Research Laboratory (United States) Timothy J. Klausutis, Air Force Research Laboratory (United States) Wolfgang Kober, Data Fusion Corporation (United States)

Aaron D. Lanterman, Georgia Institute of Technology (United States)

Randolph L. Moses, The Ohio State University (United States)

Robert R. Muise, Lockheed Martin Missiles and Fire Control (United States)

Nasser M. Nasrabadi, U.S. Army Research Laboratory (United States) Les Novak, Scientific Systems Company, Inc. (United States) Joseph A. O'Sullivan, Washington University in St. Louis (United States) Mubarak Ali Shah, University of Central Florida (United States)

Andre U. Sokolnikov, Visual Solutions and Applications (United States) 
Alan J. Van Nevel, Naval Air Warfare Center Aircraft Division (United States)

Bradley C. Wallet, Automated Decisions LLC (United States)

Edmund Zelnio, Air Force Research Laboratory (United States)

\section{Session Chairs}

Advanced Concept I

Firooz A. Sadjadi, Lockheed Martin Advanced Technology

Laboratories (United States)

Advanced Concept II

Patrick J. Loughlin, University of Pittsburgh (United States)

Active Sensor Processing

Nina Mahmoudian, Michigan Technological University (United States)

Advanced Sensor Processing II

Andre U. Sokolnikov, Visual Solutions and Applications (United States)

Advanced Algorithms

Izidor Gertner, The City College of New York (United States)

Facial and Activity Recognition

Robert R. Muise, Lockheed Martin Missiles and Fire Control

(United States) 